\title{
IMPACT OF WATER CIRCULATION AND DISCHARGED WASTES ON ZOOPLANKTON DYNAMICS IN THE WESTERN HARBOUR OF ALEXANDRIA, EGYPT
}

\author{
Nagwa E. M. Abdel Aziz \\ National Institute of Oceanography and Fisheries, Alexandria, Egypt
}

Key words : Western Harbour, zooplankton, discharged wastes, plankton ecology, pollution impact.

\begin{abstract}
Monthly variations of species composition and abundance of zooplankton community in the Western harbour were studied during the period from April 1999 to March 2000 in relation to the effect of water circulation and the discharged waste waters. The results indicated significant role of freshwater species (39 spp.) in the zooplakton community (111 spp.) in the harbour, providing the highest occurrence during the warm period (May-October) with the increase of discharged waters. However, spatially, the community structure showed a more or less homogenous distribution most of the year, reflecting the effect of water circulation pattern in the harbour.

Except the relatively high density in July $\left(48.4 \times 10^{3}\right.$ ind. $\left./ \mathrm{m}^{3}\right)$, the standing stock (annual average: $26.7 \times 10^{3}$ ind. $/ \mathrm{m}^{3}$ ) indicated low zooplankton production in the harbour. Copepods and tintinnids were the major component of the zooplankton stock, forming $46.4 \%$ and $24.8 \%$ of its total counts respectively, followed by freshwater ciliates and rotifers $(7.5 \%$ and $7.2 \%)$. The abundance of total zooplankton as well as each group showed seasonal variations, with the exception of the minimum and maximum values, providing two periods of different production levels. The diversity index values revealed higher diversity of tintinnids than copepods.
\end{abstract}

\section{INTRODUCTION}

The Western Harbour is the biggest and most important Egyptian harbour on the Mediterranean coast, occupying about 7.4 $\mathrm{km}^{2}$ with a maximum depth of $16 \mathrm{~m}$. It is approximately a closed elliptical basin connected to the sea through a small opening of less than $100 \mathrm{~m}$ width at its southwestern side. Inside the harbour, there are 
several small basins delivered for different maritime activities, such as oil export, imported coal and fertilizers, passengers and cargo, which affect the ecological characteristics of the area. The Western Harbour is further impacted directly by discharges of domestic and agricultural waste waters from El-Naubaria Canal $\left(90,000 \mathrm{~m}^{3} /\right.$ day $)$ and indirectly by main flow of Umum Drain to Mex Bay $\left(6.6 \times 10^{6}\right.$ $\mathrm{m}^{3} /$ day), which is composed of mixed agricultural, domestic and industrial waste waters. In addition, heavy traffic of ships and motorized boats may also affect the harbour ecosystem. Such conditions will be reflected on the biotic communities in general and plankton in particular. Although many studies have been conducted on both phytoplankton and zooplankton in the adjacent basin, Mex Bay, nothing is known about the plankton in the Western Harbour, except that on phytoplankton (Zaghloul, 1994).

The present paper is the first comprehensive study on zooplankton community in the Western Harbour, aiming at following up the monthly quantitative and qualitative variations of zooplankton composition, relative to the ecological conditions and water circulation in the harbour throughout a complete year.

\section{MATERIAL AND METHODS}

Zooplankton samples were collected monthly (April 1999 March 2000) at 6 stations from the Western Harbour, each is characterized by certain water quality (Fig. 1). A plankton net of $30 \mathrm{~cm}$ mouth diameter and $55 \mu \mathrm{m}$ mesh size was hauled vertically at a speed of $0.5 \mathrm{~m} / \mathrm{second}$ within the uppermost $10 \mathrm{~m}$ layer at each station. The samples were preserved in 5\% neutralized formaline and after settling they were concentrated to $100 \mathrm{ml}$. The standing stock (ind. $\mathrm{m}^{3}$ ) was determined from the average counts of three aliquotes of $5 \mathrm{ml}$ each.

\section{RESULTS}

Similar to any other coastal waters receiving freshwater, zooplankton community in the Western Harbour consisted of both marine (72 spp.) and freshwater (39 spp.) forms. Tintinnids showed the highest species richness (40 spp.), followed by other ciliates ( 20 spp.), copepods (13 spp.), rotifers (11 spp.) and foraminifers (11 spp.). The number of genera within these groups showed another pattern, whereas other ciliates were represented by the highest number 
of genera (20), tintinnids (14 genera) with the dominance of Tintinnopsis and Favella (13\& 8 spp. respectively). In the other groups, each genus was mostly represented by one species (Table 1). The monthly species richness in the harbour (Fig. 2) varied widely between the highest values (66, 65 \& 63 spp. respectively) in May, July and August, and the lowest one (24 spp.) in March. Throughout stations, zooplankton community attained the lowest richness (59 spp.) at station 6 , and the highest one ( $75 \mathrm{spp}$.) at station I. Similarity between the successive months in the Western Harbour indicated the occurrence of charcteristic seasonal zooplankton communities, with similarity in species composition of each community, exceeding $60 \%$ of the total number of species. Higher similarity was detected also in the community structure between the different stations, whereas similarity varied from 69 to $85 \%$. On the other hand, the number of the freshwater forms in the harbour showed monthly variations at the different stations, being pronouncedly higher during the period from May to October (Fig. 3). Out of 111 species reported in the Western Harbour, only 15 species could be encountered as perennial spccies, existing in the area most of the year ( $8-12$ months). These species were Difflugia lebes, Eutintinnus lusus-undae, Favella ehrenbergii, F.markuzowskii, Tintinnopsis beroidea, T. cylindrica, Synchaeta okai, S. pectinata, Acartia clausi, Euterpina acutifrons, Oithona nana, $O$. plumifera, Paracalanus parvus, Oikopleura dioica and $O$. longicauda. All other species were recorded either occasionally or during one or two seasons.

The Western Harbour was apparently poor in zooplankton stock, which varied monthly from a minimum of 10,396 ind.$/ \mathrm{m}^{3}$ in March to a maximum of $48,385 \mathrm{ind} . / \mathrm{m}^{3}$ in July. Excluding these extremes, the seasonal abundance of standing stock (Fig. 2) showed two periods of different magnitudes, the first one occurred in April, August and September, amounting to $18 \times 10^{3}-21 \times 10^{3} \mathrm{ind} . / \mathrm{m}^{3}$, and the higher one was obtained in May, June and October-February, falling within the range of $26 \times 10^{3}-32.6 \times 10^{3}$ ind. $/ \mathrm{m}^{3}$. Throughout stations, the annual density experienced little variations (Fig. 4), whereas it fluctuated between 25,853 and 30,798 ind. $/ \mathrm{m}^{3}$, except the significantly lower value $\left(19,651\right.$ ind. $\left./ \mathrm{m}^{3}\right)$ at station IV (Fig.4). The zooplankton stock was represented by adult holoplankton species $(60 \%)$, copepod larvae (30\%), and meroplanktonic larvae (10\%). 
Twelve species only were responsible for the major population density, constituting collectivelly $80 \%$ of the total holozooplankton and $49 \%$ of total zooplankton (Table 2). However, these species showed different seasonal abundances, whereas some of them predominated once or twice a year, while others were dominant during several months (Table 3).

As shown in Table 4, copepods and tintinnids constituted the greatest part of the zooplankton stock ( 46.5 and $24.8 \%$ respectively), meanwhile, other ciliates and rotifers showed an active contribution to the total abundance forming 7.5 and $7.2 \%$ respectively. The abundance of such groups demonstrated pronounced variations among different months and stations. Copepods appeared to be most productive during the period October-December, while they showed the lowest production in July, August and February (Fig. 5). Nauplii larvae were the major component of copepod stock, forming 49-71\% throughout the year. Oithona nana had the first order of abundance among copepods most of the year (Table 3), reaching the maximum $(14.7 \%$ of total zooplankton) in November. O. plumifera appeared frequently as dominant species, attaining the highest density $(11 \%)$ in September. Both Paracalanus parvus and Euterpina acutifrons demonstrated occasionally high density (Table 3 ). Spatial distribution of copepod stock demonstrated small difference between stations (Fig.4), however, the highest one was detected at station VI and the lowest at station IV. The second important group; tintinnids, had two distinctive peaks in July and February, but they showed small counts over the year (Fig. 5). Three species of this group ( $F$. markuzowskii, E. lusus-undae and Favella azorica) contributed in the dominance of July community, forming together $30.1 \%$ of the total count (Table 3 ), while in February, Tintinnopsis beroidea was absolutely the dominant species ( $82.2 \%$ of total zooplankton). Other species had relatively high stock in different months (Table 3). Spatially, like copepods, tintinnids attained the lowest count at station $\Gamma$, while the highest one appeared at stations I. At other stations, tintinnid stocks were approximately closed (Fig. 4). The monthly abundance of rotifers indicated one remarkably high peak in June, mainly due to Synchaeta okai $(36.7 \%$ of total count) but they appeared in very low density over the year (Fig. 5). Throughout stations, their abundance demonstrated relatively little variations, except station I, which harboured a population of about two times greater than the other stations (Fig. 4). The freshwater ciliates had also a pronounced role in the abundance 
of zooplankton community in the Western Harbour, forming about $7.5 \%$ of the annual average count, providing more active contribution in July and August ( $32 \& 26 \%$ respectively) due to the dominance of Oxytricha fallax. Polychaete larvae appeared as the major component of meroplankton in the harbour, constituting $9.2 \%$ of total zooplankton, increasing to $22 \%$ in May. Other benthonic larvac were mostly found in small numbers, except slightly high values of cirripede larvae. The diversity index of total zooplankton (Fig. 6) showed wide range of monthly variation (0.89-2.76). The communities of July and August sustained the lighest diversity index, coinciding with the greatest number of species while that of February exhibited the lowest one. On the other hand, the diversity of the major groups, copepods and tintinnids, showed more or less different monthly patterns, whereas tintinnids had the highest diversity during July and significantly lower one in October, November and February, and for copepods it was the greatest in November and approximately within very narrow range (1-1.44) during the rest of the year.

\section{DISCUSSION}

The discharged waste waters to the Western Harbour as well as the maritime activities appeared to be the causes of seasonal and spatial variations of the water quality, which are governed by the water circulation in the harbour. According to Farag (1982), there is a current flowing from inside to outside the harbour within the upper $5 \mathrm{~m}$ layer, with a direction varying between southeast and southwest during summer and autumn and between west and south during winter and spring. Another current flowing at $10 \mathrm{~m}$ depth from outside to inside the harbour was recorded to be directed to north-northeast during winter and summer, and between southwest and north during autumn and spring. Further, the water of the Western Harbour being completely changed within about 30 days (El-Gindy, 1986 and Hassan and Saad, 1996). The continuous discharge of the waste water caused the increase of nutrient salts (Shraidah and Tayel, 1992; Abdel-Aziz and El-Deeb, 2001) and heavy metals such as Zn (41.05 $\mu \mathrm{g} / 1), \mathrm{Cu}(5.1 \mu \mathrm{g} / \mathrm{l}), \mathrm{Cd}(5.2 \mu \mathrm{g} / \mathrm{l})$ and $\mathrm{Pb}(1.37 \mu \mathrm{g} / \mathrm{l})($ Tayel et al., 1997). On the other hand, the salinity was also exposed to wide variations between $26.3 \%{ }^{\circ}$ and $39.9 \%{ }^{\circ}$ (Dorgham and Abdel-Aziz, 2001). 
The structure of zooplankton community in the Western Harbour seems to be affected largely by the discharged waste waters entering the harbour directly from El-Noubaria Canal, or indirectly through the water current from Umum Drain. This was clearly indicated from the existence of 39 fresh and brackish water forms in the harbour, fluctuating monthly in number with the variations in the quantity of the discharged waters. Water quality at the sampled stations was also reflected on species distribution throughout the harbour, whereas Bursaridium sp., Codonellopsis orthoceras, Tintinnopsis plagiostoma, Globorotalia truncatuloides, Spirillina vivipara and Conchoecia oblusata were restricted to station I, Trochilia sp., Proplectella pentagona, Rhabdonella spiralis and Tintinnopsis vosmaeri at station II, Favella fistulicauda, Phialidium hemisphericum and Microsetella rosea at station III, Acropisthium sp., Aspejoia sp., and Achromadora sp.at station IV and Strongylidium sp.at station V.On the other hand, salinity variations influenced the species richness of zooplankton, which showed the highest values at low salinity of $31.5-35.0 \%$ in May, July and August, and the lowest one at markedly higher salinity $\left(38.8 \%{ }^{\circ}\right)$ in March. Among stations, the highest species richness, diversity index and densest population were found at station I, which is located away from Umum Drain and El-Noubaria canal. However, a relatively lower diversity index and large population density were found at station $V$ which is affected by raw coal heaped up on a neighbouring plateform and oil products discharged from the anchoring ships. Apostopoulou (1981) observed that the partial pollution by sewage and mineral oil produces more zooplankton abundance and low diversity.

Although the number of freshwater forms constituted $35 \%$ of total number of zooplankton species in the Western Harbour, a few of them were found in relatively dense population, namely Oxytricha fallax, Synchaeta okai, S. oblonga and S. pectinata. This may indicate that these species could tolerate the high salinity in the area, while all the other freshwater species had no such ability, since they were found in very small numbers throughout the year (Table 1). The abundance of freshwater forms in the harbour may be related to their flourishing times in the original habitats, whereas each of them showed the greatest density in the harbour during a certain time of the year. In contrast, the majority of the marine species may be susceptible to the water quality in the harbour, as many of them could not establish healthy populations, but several species attained high 
density at all stations, indicating that they could adapt to the different water qualities in the harbour. These species were $F$. markuzowskii, Metacyiis mediterranean Tintinnopsis beroidea, Euterpina acutifrons, Onana, O.plumifera, Paracalanus parvus and Oikopleura dioica.

The seasonal variability in quantity of the discharged waste waters into the Western Harbour was clearly detected from the variable role of freshwater forms in the zooplankton stock. During the period from May to August, freshwater ciliates and rotifers demonstrated active contribution forming, 3.5-32\% and $4.8-37 \%$ of the total zooplankton respectively and associating with the highest richness of freshwater forms. During October-December, the effect of discharged waste waters was the lowest, providing small numbers of freshwater forms, and in contrast gave a chance to the appearance of large numbers of marine species. However, high numbers of freshwater species were recorded at stations III and V, reflecting the limited effect of El-Naubaria canal water on the neighbouring area during this period. On the other hand, the quantitative and qualitative roles of main zooplankton groups appeared to be variable with the variability of the ecological conditions. The order of abundance of copepods, tintinnids and rotifers in the Western Harbour was similar to that found in Abu Qir Bay (average salinity: $33.39 \%{ }^{0}$ ) (AbdelAziz, 2001), tintinnids were the leading group in Dekhaila Harbour (average salinity: $26.4 \%$ ) (Abdel-Aziz, 2000), while the species richness of the three groups followed the same sequence in the three regions. The dominant copepods in the Western Harbour $(O$. nana, $O$. plumifera, $P$. parvus and $E$. acutifrons) were also dominant in both Au Qir Bay and Dekaila Harbour (Abdel-Aziz, 2000 \& 2001)

Tintinnids had the highest species richness (40 spp.), meanwhile they occupied the second order of abundance after. copepods, forming $24.8 \%$ of the total count. Five species only could: form dense populations, mostly during certain time of the year, with: abundance ranked as follows: T. beroidea $>F$. Markuzowskis $M$. mediterranean $E$. lusus-undae $>F$. azorica. Such pattern may be atributed to seasonal changes of water temperature and salinity variations. In other coastal waters of similar conditions like Abu Qir Bay and Dekhaila Harbour, tintinnids formed $27.8 \%$ and $65 \%$ of total zooplankton respectively, with the dominance of $F$. markuzowskii, 
Stenosemella nivalis, T. beroidea, T. cylindrica, T. nordguistii, in Abu Qir Bay (Abdel-Aziz, 2001) and Favella serrata, T. lata, $T$. compressa, $T$. radix $E$. lusus-undae, Stenosemella nivalis, $M$. medilerranean, M. mereschkowskii, and Protorhabdonella simplex in Dekhaila Harbour.(Abdel-Aziz, 2000). The relatively high abundance of both copepods and tintinnids in the harbour as a polluted area is in agreement with Blanco, et al. (1990). On the other hand, the pronounced occurrence of rotifers and ciliates could be considered as indicalor of the freshwater discharge to the area, since the organic pollution enhance the survival of protozoa (John \& John, 1970).

Except the pronouncedly lower values $\left(19.6 \times 10^{3}\right.$ ind. $\left./ \mathrm{m}^{3}\right)$ at station $\mathrm{IV}$, the annual average $\left(25.8 \times 10^{3}-30.8 \times 10^{3}\right.$ ind $\left./ \mathrm{m}^{3}\right)$ reflected the role of water circulation in the homogenous distribution of zooplankton stock in the harbour. But slight spatial differences were detected for the density and number of species of freshwater forms, indicating the effect of water quality. At staion $I$, which had average salinity of $34.3 \%$ and is affected indirectly by the discharge of Umum drain, 15 freshwater species were recorded throughout the year, amounting totally to 4242 ind. $/ \mathrm{m}^{3}$, while station V(average salinity: $35.7 \%$ ), which is affected by freshwater from El-Naubaria Canal, fertilizers and raw coal heaped up on the neighbouring platforms, 25 freshwater species were recorded, having an annual average density of 7993 ind. $/ \mathrm{m}^{3}$. This means that the number of freshwater forms transferred by El-Naubaria Canal to the Western Harbour was greater than that brought through Umum Drain.

The abundance of zooplankton in the harbour was generally low except the relatively high peak at July, indicating the unfavourable conditions for healthy zooplankton population. Even though; the clear seasonal variations of zooplankton stock appeared to be related to changes in the ecological conditions in the area, such as salinity and temperature. The peak of July coincided with high water temperature $\left(28^{\circ} \mathrm{C}\right)$ and low salinity $(31.5 \%$ ), while the lowest count was found in March accompanied by low temperature $\left(18{ }^{\circ} \mathrm{C}\right)$ and high salinity (38.8\%o). The high count at July can be referred mainly to the active contribution of the freshwater ciliate Oxytricha fallax, which formed $32 \%$ of total zooplankton. This may point to two facts, the first one: such species showed maximum growth in its original habitat (Lake Mariut) at July, and moving to the Western Harbour through El-Noubaria Canal. The second fact: the water discharge from this canal reaches the greatest volume at July. The 
Latter fact is more reasonable and in good agreement with the low salinity at July ( $31.5 \%$ ). Other species like Fovella markuzowskii, E. lusus-undae, $F$. azorica, $P$. simplex, $S$. nivalis, $T$. cylindrica, and $S$. oblonga attained abnormally higher counts at July as compared to other months, forming collectively $46 \%$ of July zooplankton. Such case may indicate that these species prefer low salinity (31.5\%) and high temperature $\left(28^{\circ} \mathrm{C}\right)$, while low temperature $\left(18^{\circ} \mathrm{C}\right)$ and high salinity (38.8\%) at March appeared to be unfavourable for many of species existing in the Western Harbour. Water pollution is another reason which could be encountered for such low stock in March in particular, and throughout the year in general. Tayel, et al. (1997) reported that the highest concentrations of trace metals in the Western Harbour were recorded during winter duc to the intensive mixing of water column and the lowest ones during summer as a result of their uptake by phytoplankton and due to the stability of water column which leads to increase of the sedimentation rate of particulate matter.

The seasonal abundance of different groups showed that rotifers attained their maximum abundance during June, constiluting $42.4 \%$ of the total zooplankton at water temperature of $28^{\circ} \mathrm{C}$ and salinity $35.7 \%$, tintinnids in July and February at temperature of $28^{\circ} \mathrm{C}$ and $14^{\circ} \mathrm{C}$ and salinity $31.5 \%$ and $32.5 \%$ respectively. Copepods were the most abundant component from October to December at temperature range of $19-26^{\circ} \mathrm{C}$ and salinity of $36.1-39.1 \%$.

The diversity of the two major groups, copepods and tintinnids, showed different seasonal patterns and variation ranges. The low diversity index of copepods $(1.0-1.8)$ may be attributed to their low richness of species. The wider range of tintinnid diversity $(0.27-2.4)$ may be referred to the high species richness and the intermittent abundance of this group. The lowest diversity index of tintinnids was found in February with the lowest population density and the highest value in July, accompanying their maximum abundance. Magurran (1988) stated that diversity has always been used as an index of the ecosystem well being with species rich communities being healthier than those poor in species numbers. The present study showed that the highest diversity index of total zooplankton was found in summer and the lowest in winter. This is in agreement with Michael (1984) who noticed that the diversity 
increases as the community becomes more stable, while severe disturbances cause a marked decline in diversity.

One of the characteristic features of zooplankton in the Western Harbour was the the pronounced seasonal changes in the community structure, indicating the occurrence of different seasonal communities. This may reflect the effect of seasonal variations in the water cirulation in the harbour and rapid change (every 30 days) of its water (El-Gindy, 1986; Hassan and Saad, 1996), which, on the other hand, caused a great similarity between stations with index values varying from $68 \%$ to $85 \%$. Matching the number of freshwater species at different stations with the seasonal variations of the water currents entering the harbour (Farag, 1982), it seems that the community structure at stations II- $\mathrm{V}$ is possibly affected by the outflowing current, which is directed southeast, southwest during summer and autumn and west and south during winter and spring. Freshwater forms are transferred to the harbour through Umum Drain and E1-Noubaria Canal, but apparently the latter is the major source of these forms, whereas their numbers (24-29 spp.) at stations III,IV and $V$, which are affected by El-Noubaria Canal were greater than those (15-21 spp.) at other stations, which are affected by Umum Drain. In contrast, the numbers of the marine species showed opposite spatial distribution to that of freshwater, since they were greatest at stations.I, II \& VI, which are located nearby the open sea water, while the lowest numbers were found at stations IV \& V which are affected directly by EL-Noubaria Canal.

\section{REFERENCES}

Abdel-Aziz, M. and El-Deeb, K. (2001). Nutrient Budjet in the Western Harbour. Nat. Inst. Oceanogr. and Fish. (In press)

Abdel-Aziz, N. E. (2000). Zooplankton dynamics and ecology of an eutrophic area, Egypt. Arab Gulf J. Sci. Res., 18(2): 110121.

Abdel-Aziz, N. E. (2001). Zooplankton community under the stress of polluted land based effluents in Abu Qir Bay, Alexandria, Egypt. Bull. Fac. Sci, Alex. Univ., 41(1,2). 
Apostopoulou, M. M (1981). The annual cycle of zooplankton in Elefsis Bay (Greece). Rapp. Comm. Int. Mer. Medit., 27(7): 105-106.

Blanco, C. Rois, C.; Rois, C; R.; Raduan, A.; Saler, E. and Del.Rio, J. G. (1990). Waste influence on zooplankton distribution in Valencia coastal water (Spain). Rapp. Comm. inter. Mer. Medit., 32 (1).

Dorgham, M. M. and Abdel-Aziz, N. E. (2001). Eutrophication problem in the Western Harbour of Alexandria, Egypt. EMECS2001(5th intern. Conf. on the Environmental Management of Enclosed Coastal Seas), 19-22 November, Kobe, Japan.

El-Gindy, A. A. H. (1986). Estimation of water exchange and residence time of the Western harbour of Alexandria. Rapp. Comm, inter. Mer. Medit., 32 (2).

Farag, M. (1982). Circulation patterns and hydrogtaphic structure of El-Mex and Western Harbour area. M. Sc.Thesis, Fac. Sci., Alexandria Univ., Egypt.

Hassan, M. H. and Saad, N. N. (1996). Some studies on the effect of Alexandria Western Harbour on the coastal waters. Sixth international conf. on "Environmental Protection is a Must", Alexandria, Egypt, 464-478.

Jahn, T. L. and Jahn, F. F. (1970). "How to Know the Protozoa." Second eddition. W. M. C., London, 234pp.

'Magurran, A. E. (1988). "Ecological Diversity and its Measurment." Croom Helm. London, $179 \mathrm{pp}$.

Michael, P. (1984). "Ecological Methods for Field and Laboratoty Investigations." Tato Mc Graw-Hill. Publishing Co. Ltd. New Delhi, First edition; 404 pp. 
Shriadah, M. M. A. and Tayel, F. T. (1992). Environmental conditions of the Western Harbour of Alexandria, IPhysico-chemical charactertistics. Bull. High Inst. Pub. Health, Alexandria, Egypt, 22(3): 213-228.

Tac yel, F. T. R.; Shriadah, M. M. A. and El-Shenawy, M. A. (1997). The occurrence of Zinc, Copper, Cadmium and Lead in the sea waters of the Alexandria, Harbour, Egypt. $7^{\text {th }}$ international conference on "Environmental Protection is a must," Alex.Egypt, 106-117.

Zaghloul F. A. (1994). Phytoplankton dynamics in the Western Harbour of Alexandria Egypt. Bull. Nat. Inst.Oceanogr.and Fish., 20 (1): 107-117. 


\section{IMPACT OF WATER CIRCULATION AND DISCHARGED WASTES ON ZOOPLANKTON DYNAMICS IN THE WESTERN

Table 1- The annual average density of zooplankton species in the Western Harbour (April 1999-March 2000).

\begin{tabular}{|c|c|c|c|}
\hline Species & Count $/ \mathrm{m}^{3}$ & Species & Cound/m ${ }^{3}$ \\
\hline \multicolumn{4}{|l|}{ CILIATES } \\
\hline dimeria sp & 74.7 & Tintinnopsis beroidea & 2.370 \\
\hline Acluropisthimm sp. & 0.5 & T. butschilii & 24.3 \\
\hline Amphilepus claparedei & 19.0 & T. campanula & 10.8 \\
\hline Aspejoiasp. & 0.8 & T. compressa & 40.0 \\
\hline Bursaridium sp. & 0.5 & T, cylindrica & 147.2 \\
\hline Crasotheridium sp. & 2.8 & T. levigaia & 260 \\
\hline Difhugia lebes & 229.3 & T. lindeni & 9.8 \\
\hline Enclielyoton sp. & 12.8 & T. lobiancoi & 9.7 \\
\hline Euploles sp. & $3 i .0$ & T. nana & 19.5 \\
\hline Glaucoma scintillans & 1.7 & T. nordgnisfi & 7.2 \\
\hline Holophrya sp. & 13.2 & T. plagiostoma & 10.8 \\
\hline Oxytricha fallor & 1492.0 & 7. radix & 1.2 \\
\hline Plagiopyla sp. & 57.2 & T. vessmaeri & 0.3 \\
\hline Platioplroga sp. & 15.3 & FORANÝMINTHERA & \\
\hline Spirosionumn sp. & 1.2 & Adelosina elegans & 1.0 \\
\hline Sirombidinm sp. & 21.5 & Ammonia beccaril & 6.7 \\
\hline Sirongyildium sp. & 0.8 & Cycloforina contoria & 5.8 \\
\hline Tetrabymena sw. & 8.7 & Globigerina bulloides & 3.0 \\
\hline Trocinitia sp. & 6.3 & G. inflata & 14.3 \\
\hline Trochiliussp. & 5.7 & Globorolalia truncatulordes & 0.3 \\
\hline TINTINNIMS & & Loxostomnum picslinm & 3.7 \\
\hline Codoncila gutua & 3.0 & Qnimqueloculina striaia & 0.8 \\
\hline ('odonellopsis lata & 34.7 & Spirilline vivipara & 4.8 \\
\hline C. morchella & 26.3 & Spiroloculina limbala & 0.1 \\
\hline C. orthoceros & 1.8 & Texiulariu sp. & 1.8 \\
\hline Condiellu anpla & 31.2 & COELENTCRATFS & \\
\hline C. anmulaia & 12.0 & Ectoplemra dimortier; & $0 .:$ \\
\hline Epiplacylis undella & 19.3 & Obcliasp & 14.3 \\
\hline Eunintinnus lusus-undae & 351.2 & Phichidiun hemisphericum & $0 . \dot{8}$ \\
\hline E. uncilentus & 4.7 & ROTITERS & \\
\hline Fuvella attingata & 9.3 & Ascomorpha'sallans & 23.2 \\
\hline F. azoricir & 282.7 & Asplenclinu priodonía & 0.5 \\
\hline$\because$ compositu & 71.7 & Brachivonus plicallis & 3.2 \\
\hline F. ettrenbergii & 155.7 & Colurella oblusa & 0.8 \\
\hline F. fistulicaudo & 0.3 & Keratella cochlearis & 0.1 \\
\hline F. helgolandica & 11.2 & K. quadrala & 0.1 \\
\hline F. murhirzonskii & 1685.0 & Synchueto grinjpei & 110.0 \\
\hline F. serrata & 3.0 & S. oblonga & 280.0 \\
\hline Helicosiomella subulata & 7.3 & S. okat & 1317.0 \\
\hline Mencylis mereschouskij & 52.7 & S. peclinala & 179.3 \\
\hline W. mediterranean & 678.0 & Trichocerca cylindrica & 16.3 \\
\hline Purimdella lachmanni & 169.3 & NEMATODS & $\cdot$ \\
\hline Propleciella angusia & 0.1 & Acliromadorasp. & 0.5 \\
\hline P. pentagona & 1,2 & Anmplecius sp. & 8.5 \\
\hline Protorhabdonella simplex & 91.2 & Aphanola'mus sp. & 12 \\
\hline Rhabclonella spiralis & 0.2 & Aphlanchoides sp. & 3.8 \\
\hline Stenosentella misalis & 193.0 & Dolichoderus sip. & 4.5 \\
\hline S. ventricosa & 48.2 & Doryiluimus sp. & 2.5 \\
\hline
\end{tabular}


Table 1- continued

\begin{tabular}{|c|c|c|c|}
\hline Species & Count $/ \mathrm{m}^{3}$ & Species & $t^{\prime} m^{3}$ \\
\hline COPEPODS & & OSTRACODS & \\
\hline Acanthocyclops americanus & 0.1 & Conchoecja elegans & 0.1 \\
\hline Acartier clausi & 85.5 & C. obtusata & 0.2 \\
\hline A. grani & 10.3 & Cypridina medirerranean & 6.2 \\
\hline Centropages kroyeri & 3.7 & LARVACEAE & \\
\hline Clousocalamus arcuicornis & 22.8 & Oikopleura diofca & 597.5 \\
\hline Euterpina ucutifrons & 645.0 & O. longicauda & 197.7 \\
\hline Microselella rosea & 0.8 & CHAETOGNATHS & \\
\hline Nirocera lacustris & 0.1 & Sagitla friderici & 17.3 \\
\hline Oilhona nana & 2096 & \multicolumn{2}{|c|}{ MEROPLANKTONIC LARVAE } \\
\hline O. plunifera & 1077.7 & Ascidian larvae & 25.8 \\
\hline Oncaea venusta & 0.1 & Polychaete iarvae & 2461.0 \\
\hline Paracalanus parvus & 464.0 & Cirriped larvae & 266.3 \\
\hline P. pygmaeus & 11.7 & Decapod larrac & 0.2 \\
\hline Copepod nauplii & 7326 & Gastropod veligers & 0.2 \\
\hline Copcpodile stages & 690 & Lamellibranch veligers & 10.7 \\
\hline CLADOCERAS & & Phoronid larvae & 0.2 \\
\hline Podon polyphemoides & 94.3 & Total & 26737 \\
\hline
\end{tabular}

Tabje 2- The perennial and temporal dominant adult holozooplankton species in the Western Harbour (April 1999-March 2000)

\begin{tabular}{|c|c|c|c|}
\hline Species & $\begin{array}{l}\% \text { of ann. } \\
\text { aver. count }\end{array}$ & Species & $\begin{array}{l}\% \text { of ann. } \\
\text { aver. Count }\end{array}$ \\
\hline Tintinnopsis beroidaa & 14.9 & Metacylis mediterranean & 4.2 \\
\hline Oithona nana & 13.1 & Euterpina ccutifrons & 4.1 \\
\hline Favella markwzowzkil & 10.6 & Oikopleura dioica & 3.7 \\
\hline Oxytricha fallax & 9.4 & Paracalamus parvus & 2.9 \\
\hline Synchueta okai & 8.3 & Eutimtinnus lusus-undae & 2.2 \\
\hline Oithona piumifera & 6.8 & Favella azorica & 1.8 \\
\hline
\end{tabular}


Table 3- The monthly dominant zooplankton species in the Western Harbour (April 1999-Marcli 2000).

\begin{tabular}{|c|c|c|c|}
\hline species & $\%$ of total & Species & Lotal \\
\hline \multicolumn{2}{|l|}{ April 1999} & \multicolumn{2}{|l|}{ Octoher } \\
\hline 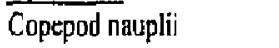 & 33.5 & $\overline{\text { Copepod nauplii }}$ & 43.2 \\
\hline Polychaete larvae & $: 6.0$ & Metacylis nediterranean & 16.4 \\
\hline Oikopleura longicauda & 10.7 & O nana & 12.9 \\
\hline Euterpira acuifrons & 10.2 & O. plumifera & 9.9 \\
\hline Tintinnopsis beroideo & 5.6 & Polychaete larvae & 7.5 \\
\hline May & & Nouember & \\
\hline Copepod naupiii & 23.7 & Copepod nauplii & 39.6 \\
\hline Polychacte larvac & 22.1 & Oithona nana & 14.7 \\
\hline Favelia markzzowshii & 13.2 & Paracalantss parvas & 7.5 \\
\hline Oithona nana & 7.4 & o. plumifera & 6.6 \\
\hline 0. longicauda & 6.5 & M. mediferranean & 5.9 \\
\hline Parunde[la lachmanji & 5.3 & Oikopleura diolca & 4.3 \\
\hline June & & December & \\
\hline Synchaela akai & 36.7 & Copepod nauplii & 55.0 \\
\hline Copepod nauphii & 20.1 & O. nana & 11.0 \\
\hline Polychaete iaryas & 16.7 & O. phumitern & 8.2 \\
\hline O. nana & 9.3 & E. acultifrons & 5.8 \\
\hline $\mathrm{JuJy}$ & & P. parvus & 4.6 \\
\hline Oxpurichr fallox & 31.3 & January 20100 & \\
\hline F.markizoluskii & 16.1 & Copepod nauplii & 36.0 \\
\hline Etuminnus lusus-undac & 7.1 & T. beroldea & 20.9 \\
\hline Fovella azorica & 6.9 & f. marktizow & 13.3 \\
\hline Polychaete larvae & 5.6 & O. mana & 7.6 \\
\hline Copepod nauplii & 4.9 & Polyclinetc larvac & 5.9 \\
\hline August & & Februniry & \\
\hline Polychacte iarvne & 19.7 & 7. beroidea & 82.2 \\
\hline S. okai & 15.7 & F. marknzowskil & 4.8 \\
\hline Q. jallar & 15.1 & & \\
\hline F. markuzonskii & 11.8 & March & \\
\hline Seplember & & Copepod nauplii & 39.7 \\
\hline Copepod ausplii & 45.1 & 0. nana & 8.7 \\
\hline O. nana & 14.5 & 0. diolica & 7.0 \\
\hline Oithona plumifera & 11.0 & Cixipede larvae & 5.6 \\
\hline Polychaete larvae & 9.9 & . & \\
\hline
\end{tabular}

Table 4- The major zooplankton components in the Western Harbour (April 1999-March 2000)

\begin{tabular}{|c|c|c|c|c|}
\hline Group & $\begin{array}{c}\% \text { of tota? } \\
\text { count }\end{array}$ & $\begin{array}{l}\text { Annual } \\
\text { average }\end{array}$ & $\begin{array}{c}\text { Gejera } \\
\text { No. }\end{array}$ & $\begin{array}{c}\text { Species } \\
\text { No. }\end{array}$ \\
\hline Copepods & 46.4 & |243] & $\cdot 10$ & 13 \\
\hline Tintinnids & 24.8 & 6621 & 14 & 40 \\
\hline Ciliates & 7.5 & 1995 & 20 & 20 \\
\hline Ratifers & 7.2 & 1927 & 6 & $1 !$ \\
\hline Larwaceat & 3.0 & 796 & 1 & 2 \\
\hline Foraninifera & 0.2 & 41 & 10 & 11 \\
\hline Other holoplankton & 0.6 & 149 & 13 & 11 \\
\hline Meroplankion & 10.3 & $276 B$ & & \\
\hline
\end{tabular}



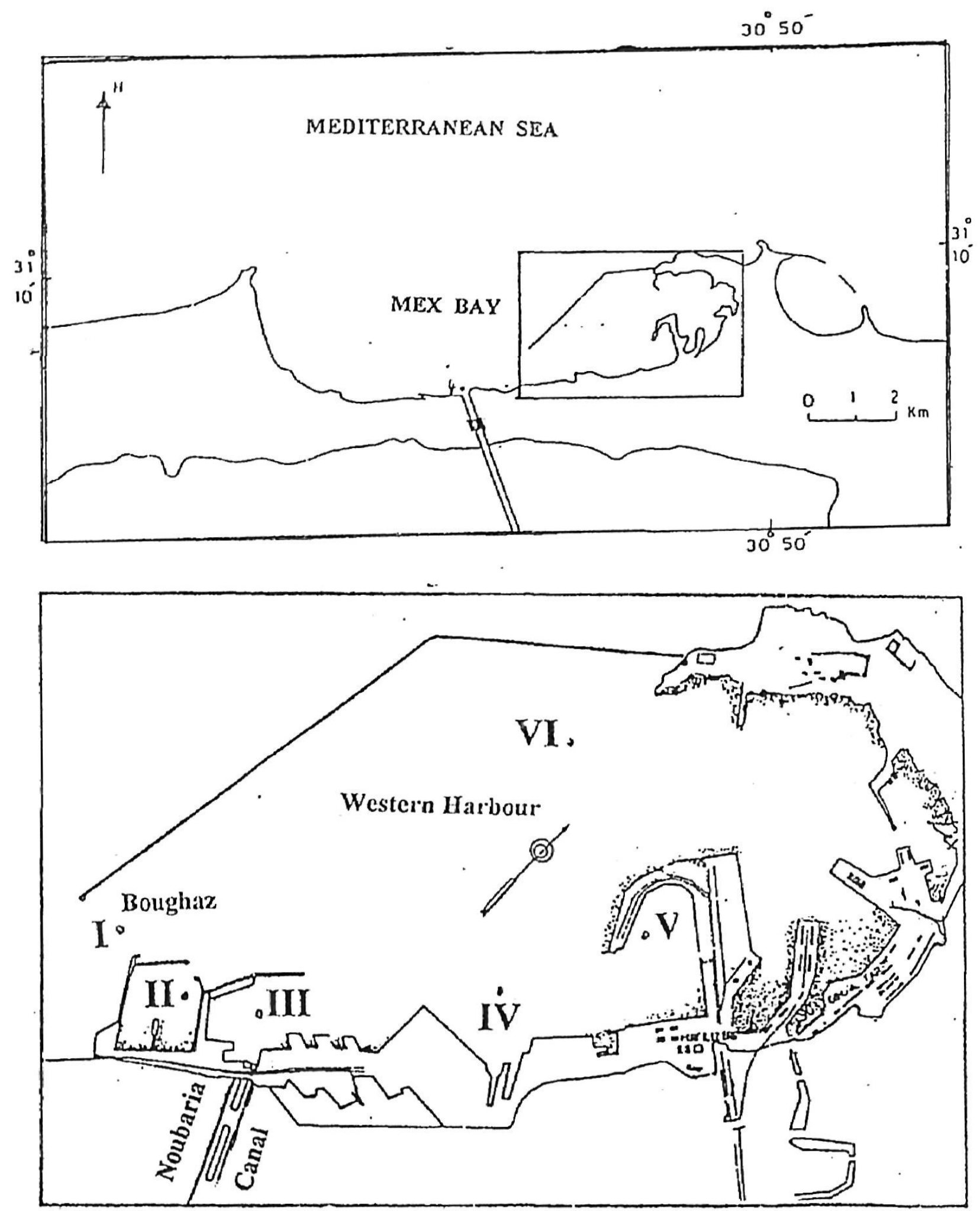

Fig. 1- The Western Harbour and the sampling locations. 


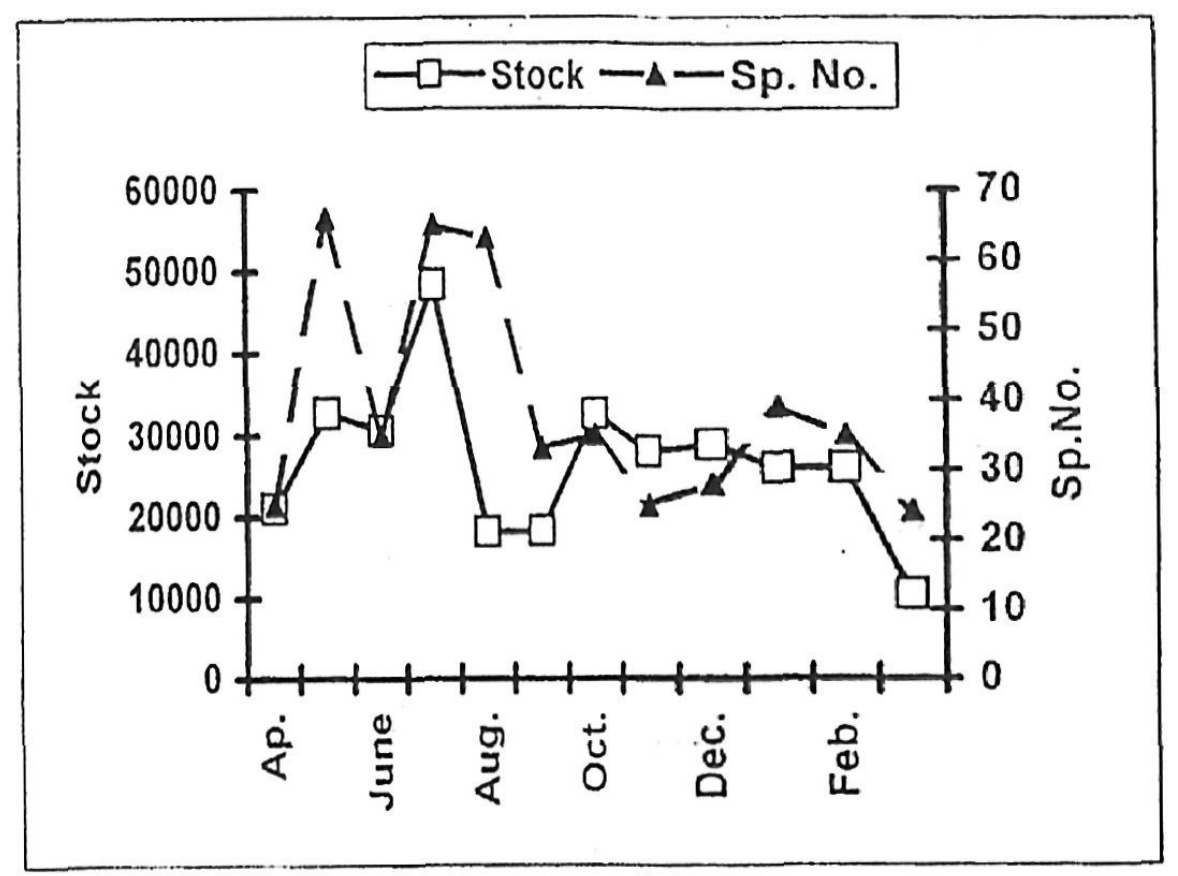

Fig. 2-Monthly abundance and species number of zooplankton in the Western Harbour (April 1999-March 2000).

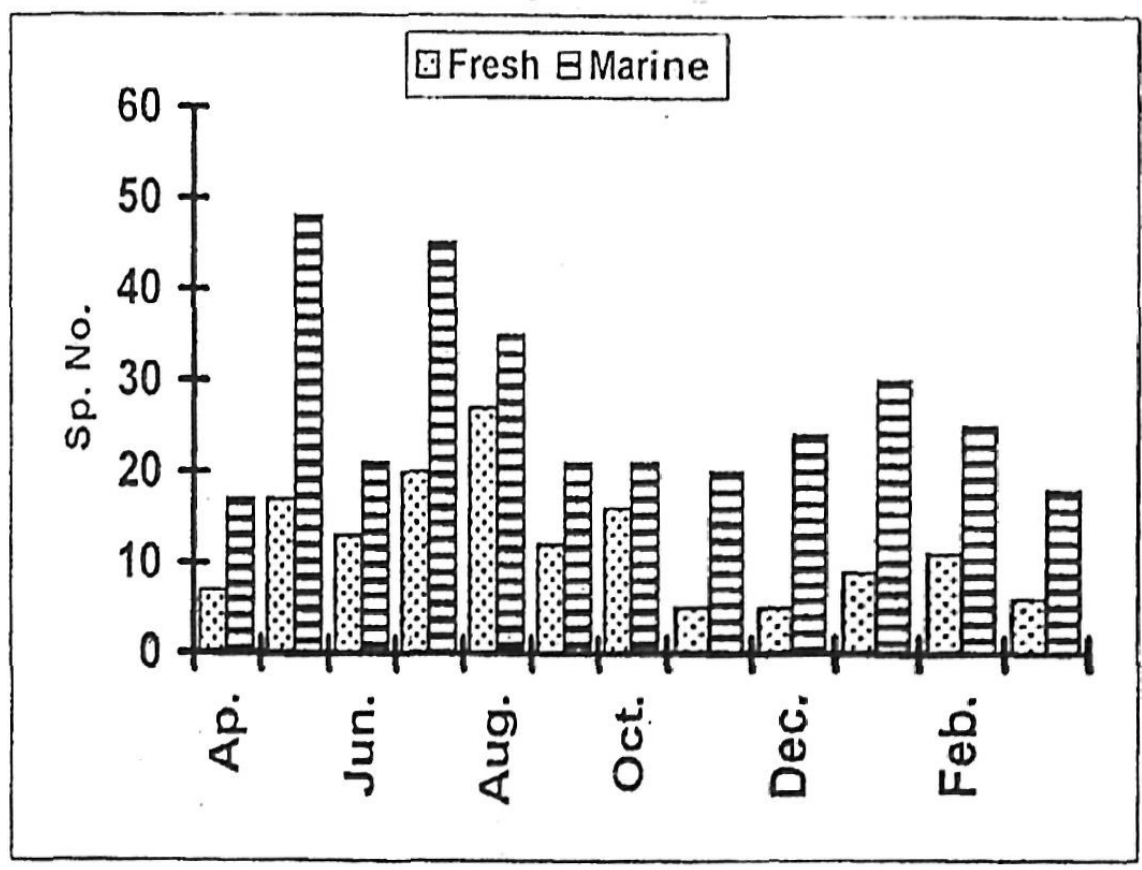

Fig. 3-Monthly variations in the number of fresh and marine zooplankton species in the Western Harbour (April 1999-March 2000). 


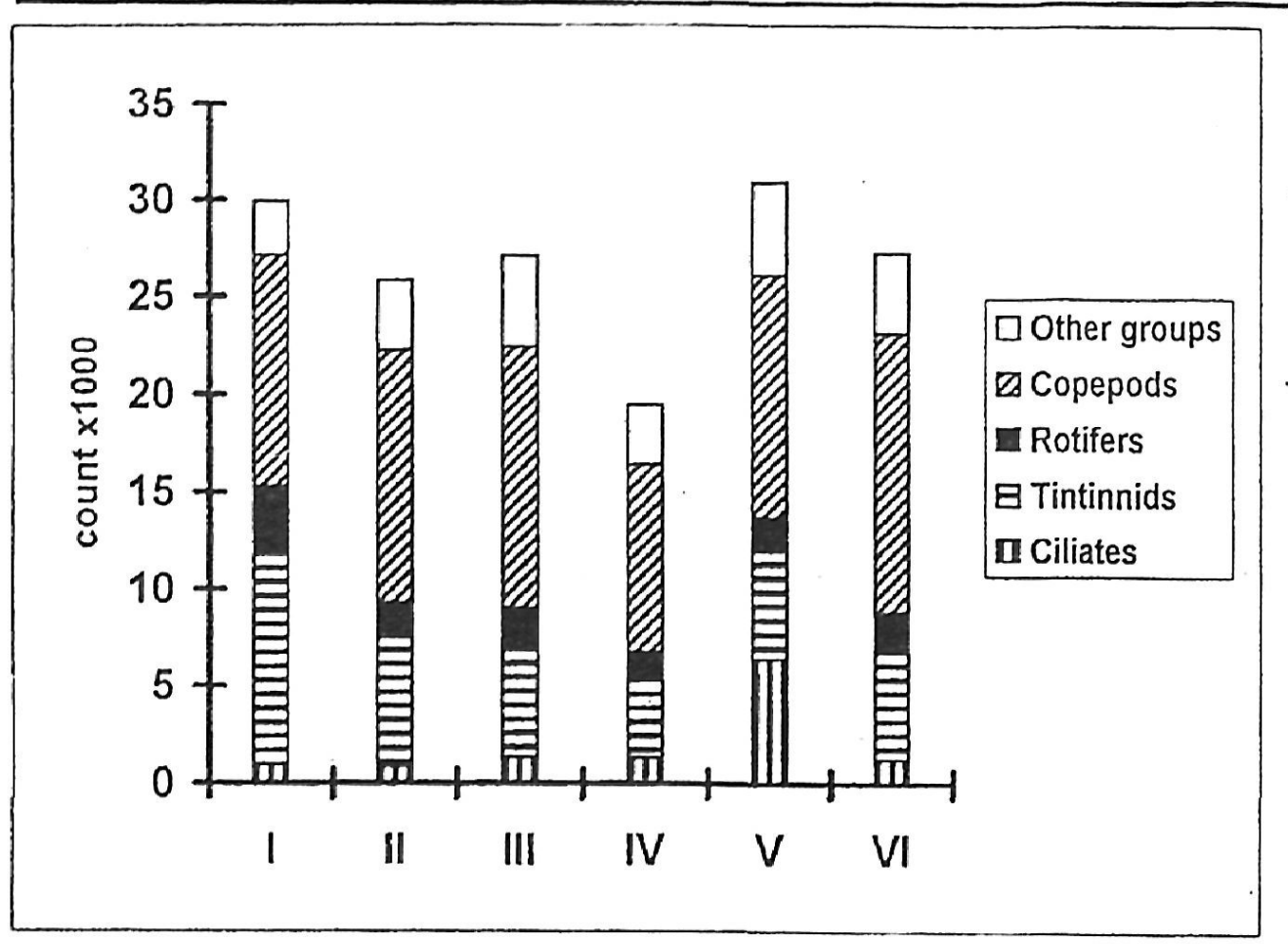

Fig. 4- The role of different groups in the annual average zooplankton stock at the sampled stations in the Western Harbour.

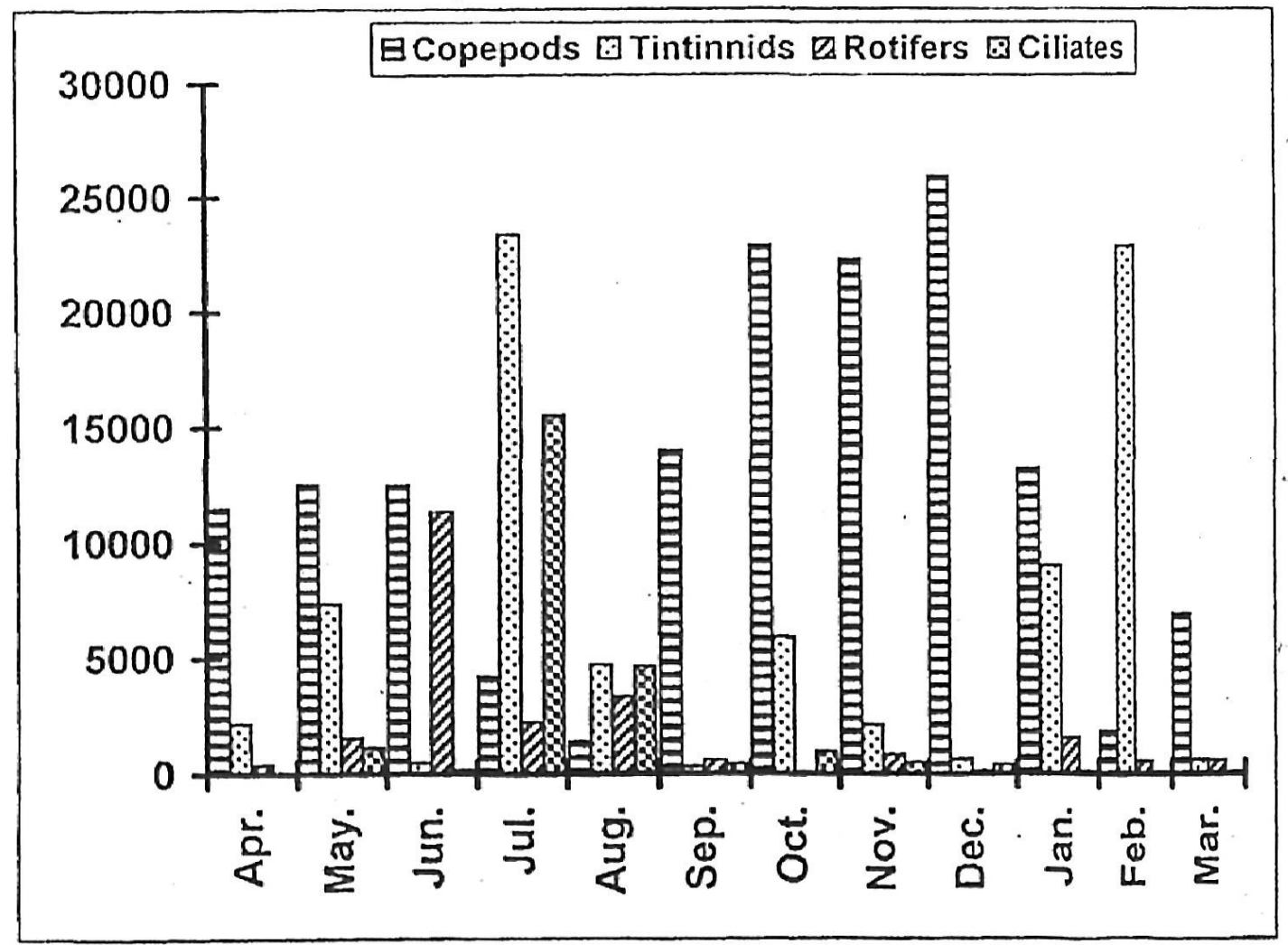

Fig. 5- Monthly abundance of dominant zooplankton groups in the Western Harbour (April 1999-March 2000). 


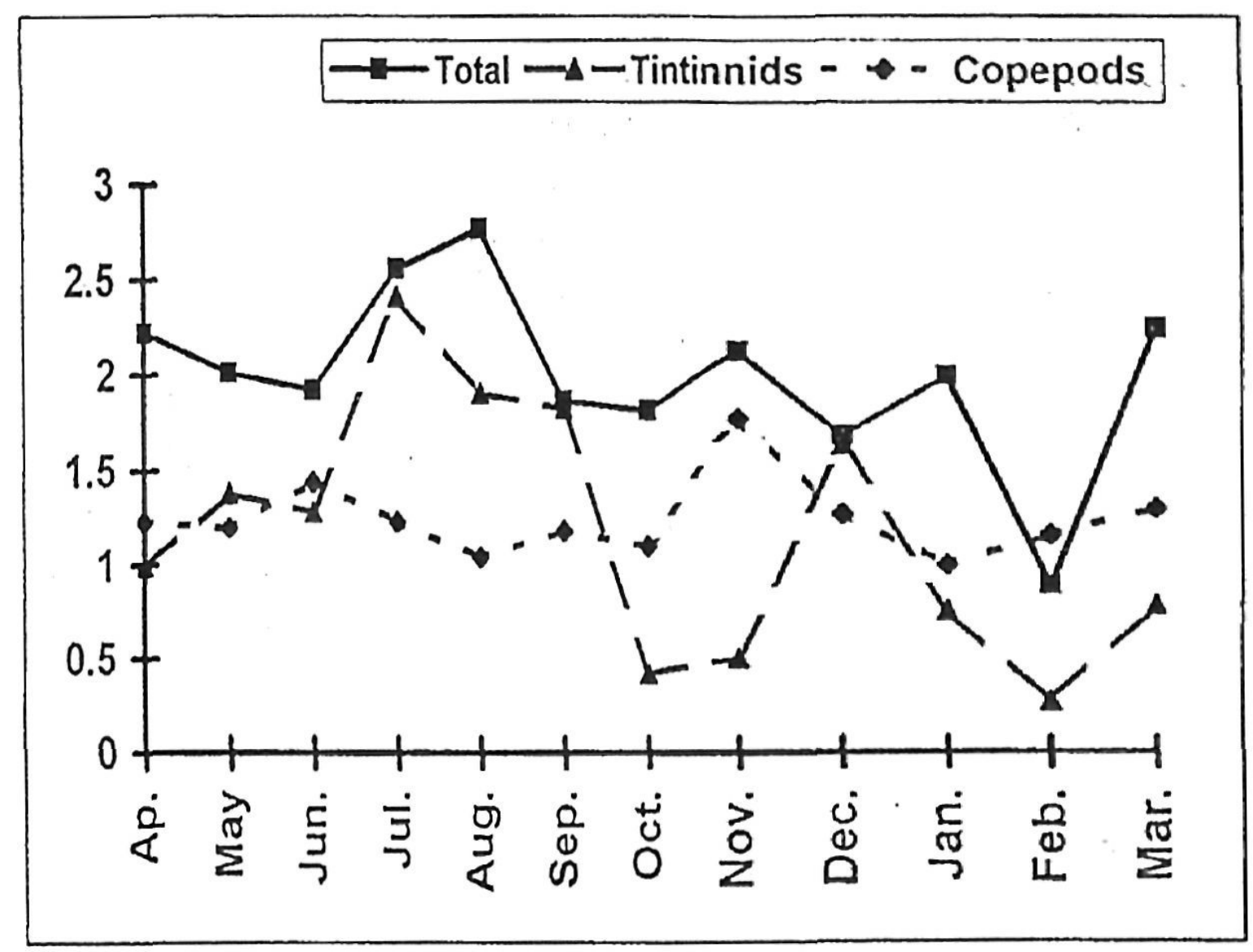

Fig. 6- Monthly variations of diversity index for copepods, tintinnids and total zooplankton in the Western Harbour (April 1999-March 2000). 